\title{
Short communication: Occurrence of aflatoxin M1 in the Manchego cheese supply chain
}

\author{
R. Rubio, ${ }^{* 1}$ C. C. Licón, ${ }^{*}$ M. I. Berruga, ${ }^{*}$ M. P. Molina, $†$ and A. Molina* \\ *Departamento de Ciencia y Tecnología Agroforestal y Genética, ETSIA-IDR, Universidad de Castilla-La Mancha, Campus Universitario s/n, \\ 02071, Albacete, Spain \\ †Instituto de Ciencia y Tecnología Animal, Universidad Politécnica de Valencia, Camino de Vera s/n, 46022, Valencia, Spain
}

\section{ABSTRACT}

The importance of ewe milk lies in the production of high quality cheeses, such as Manchego cheese with a Protected Designation of Origin, whose safety must be guaranteed. In a 2-yr study, 407 bulk tank milk samples from farms and 82 silo milk and curd samples from cheese factories were collected from southeast Spain and tested for aflatoxin M1 (AFM1) using 2 commercial ELISA tests. Of these, $99.3 \%$ of the bulk tank samples had AFM1 levels below the European Union (EU) legal limit for milk (50 ng/kg), and well below the limit adopted by the Codex Alimentarius (500 ng/kg). Moreover, $98.8 \%$ of the silo milk and curd samples from cheese factories had AFM1 levels below the EU limit for milk. When considering median AFM1 concentrations, an average 4-fold increase was found in the final curd in relation to the corresponding silo milk. Control of AFM1 in Manchega ewe milk would enhance dairy product safety by the possible detection of faults in the manufacture of Manchego cheese.

Key words: aflatoxin M1, ewe milk, curd, ELISA

\section{Short Communication}

Spain is the third-largest producer of ewe milk in the European Union (EU); ewe milk production is typical in the Mediterranean region, with an approximate production of 427,000 t/yr. Of this milk, around $44,000 \mathrm{t}$ is destined for production of Manchego cheese (MMAMRM, 2008), a product with the quality Protected Designation of Origin (PDO) label. The need for a food safety approach "from farm to fork" in relation to this product has involved the EU establishing specific hygiene rules (European Union, 2004; Regulation $853 / 2004$ ), given the possibility of microbiological and chemical hazards appearing in milk, as well as residues and contaminants such as aflatoxins (AF; European

Received November 18, 2010.

Accepted February 18, 2011.

${ }^{1}$ Corresponding author: raquel.rubio@uclm.es
Union, 1996; Directive 96/23). These mycotoxins are a group of secondary metabolites mainly produced by the filamentous fungi Aspergillus flavus, Aspergillus parasiticus, and Aspergillus nomius (Applebaum et al., 1982). Aflatoxins are an important threat worldwide given their occurrence and toxicity. Naturally occurring $\mathrm{AF}$ have been classified as Group 1 (carcinogenic to humans), whereas aflatoxin M1 (AFM1) belongs to Group 2B (possibly carcinogenic; IARC, 2002). Aflatoxin B1 is considered the most toxic compound produced by these molds; its main oxidized metabolite, AFM1, is excreted in milk when lactating animals are given feed contaminated with aflatoxin B1 (De Iongh et al., 1964). Given the health problems related to mycotoxins, at least 99 countries adopted food-feed regulations in 2003, and they have all done so for AF (van Egmond et al., 2007). In the EU, Regulation 2174/2003 (European Union, 2003) set a limit of $50 \mathrm{ng} / \mathrm{kg}$ for AFM1 in raw milk, milk destined for the manufacture of milk-based products, and heat-treated milk, whereas the Codex Alimentarius Commission (2001) established a limit of $500 \mathrm{ng} / \mathrm{kg}$. Because limits for dairy products such as cheese are lacking, some countries have established their own limits: $200 \mathrm{ng} / \mathrm{kg}$ in the Netherlands (Finoli and Vecchio, 2003), $250 \mathrm{ng} / \mathrm{kg}$ in Switzerland, Austria, and Turkey (Kaniou-Grigoriadou et al., 2005), and $450 \mathrm{ng} / \mathrm{kg}$ in Italy (Montagna et al., 2008).

The reference method used for the detection of AFM1 in milk is HPLC with fluorimetric detection (ISO, 2007). However, in the last few years, ELISA has been successfully tested for the routine analysis of AF because it is rapid and simple and offers high specificity and sensitivity (Kolosova et al., 2006). Thus, ELISA is considered the preferred method for the screening of AFM1 in both cow (Magliulo et al., 2005) and ewe milk (Rubio et al., 2009b).

Monitoring of AFM1 levels in milk is carried out in many countries given the need to lower the population exposure risk. Moreover, AFM1 contamination in manufactured dairy products is also important because this mycotoxin can appear abundantly in curd and cheese (Applebaum et al., 1982). The fact that strict limits 
RUBIO ET AL.

Table 1. Chemical composition and SCC in ewe milk and curds ${ }^{1}$

\begin{tabular}{lccc}
\hline Item & Bulk tank milk $(\mathrm{n}=407)$ & Silo milk(n=82) & Curd(n=82) \\
\hline Fat (\%) & $8.1 \pm 1$ & $7.8 \pm 1.1$ & $21.6 \pm 4.7$ \\
Lactose (\%) & $4.6 \pm 0.3$ & $4.5 \pm 0.3$ & - \\
Proteins (\%) & $6.1 \pm 0.5$ & $5.9 \pm 0.5$ & $15.8 \pm 3.4$ \\
Total solids (\%) & $19.7 \pm 1.2$ & $18.9 \pm 1.3$ & $41.2 \pm 7.5$ \\
Log $_{10}$ SCC (mL & $6.0 \pm 0.2$ & - \\
\hline
\end{tabular}

${ }^{1}$ Expressed as mean \pm SD.

have been set in the EU has favored low occurrence of this mycotoxin in cow (Boudra et al., 2007), ewe (Finoli and Vecchio, 2003), and goat (Virdis et al., 2008) milk. However, around $10 \%$ of cow, ewe, and goat cheeses have concentrations of AFM1 greater than $50 \mathrm{ng} / \mathrm{kg}$ (Montagna et al., 2008; Torkar and Vengušt, 2008; Virdis et al., 2008), and even higher (83.3\%) in ewe cheese (Kaniou-Grigoriadou et al., 2005). In Mediterranean countries where strict control strategies have not yet been developed, large amounts of this mycotoxin (over the EU limit) are found in both raw (Tajkarimi et al., 2007; Hussain and Anwar, 2008) and pasteurized milk (Oveisi et al., 2007), and up to $99.4 \%$ of samples had levels exceeding the EU limit. When cheeses were analyzed, between 30 and $81.7 \%$ presented levels exceeding $50 \mathrm{ng} / \mathrm{kg}$, with some values greater than $800 \mathrm{ng} /$ kg (Sarimehmetoglu et al., 2004; Dashti et al., 2009); these results represent a considerable health risk. However, these high contamination levels could be avoided if strict controls were established in all countries, as they have been in the EU. Given the importance of Manchego cheese, the present study was carried out to evaluate the occurrence of AFM1 in the supply chain using 2 ELISA methods in bulk tank ewe milk, silo ewe milk, and curd samples.

In the autumn and winter of 2007 and 2008, a total of 407 bulk tank ewe milk samples from different farms were randomly selected from the Castilla-La Mancha region (southeast Spain) and analyzed for the presence of AFM1; 82 silo milk samples and samples of the corresponding curds were also analyzed. Twenty-seven percent of the farms and $72 \%$ of the silos, all of which belonged to the PDO Manchego cheese, were analyzed. Samples were $50 \mathrm{~mL}$ for milk and $200 \mathrm{~g}$ for each curd, collected in hermetic containers under similar conditions. All the samples were refrigerated $\left(4-8^{\circ} \mathrm{C}\right)$ until they arrived at the laboratory. Milk samples did not contain any preservatives, thus avoiding possible interference while performing the ELISA (Rubio et al., 2009a). Composition analysis and SCC of the bulk tank and silo milk samples were determined using a CombiFoss 5000 machine (FossElectric, Hillerød, Denmark), which combines analysis by Milkoscan 4000 (infrared analysis) and Fossomatic 5000 (flow cytometry somatic cell counter), calibrated using certified standards. Curd composition was determined using a Foodscan nearinfrared analyzer (FossElectric). Two aliquots of each sample type for the AFM1 analysis were analyzed in duplicate using commercial ELISA methods: (1) Immunoscreen AFM1 (Tecna s.r.l., Trieste, Italy) and (2) Transia Plate Aflatoxin M1 (Raisio Diagnostics SAS, Lyon, France). The limit of detection (LOD) of these kits is $5 \mathrm{ng} / \mathrm{kg}$. Absorbance was measured by using a microplate reader (Original Multiskan EX, Thermo Electron Corp., Shanghai, China) at $450 \mathrm{~nm}$. The mean and standard deviation were reported for the composition results, and the median and interquartile range $\left(\mathrm{IQR}=\mathrm{Q}_{3}-\mathrm{Q}_{1}\right)$ were used to express AFM1 concentrations. A general linear model was used to determine the effect of method and year on the level of AFM1 in the 3 sample types analyzed. The equation for this analysis was

$$
\mathrm{y}_{\mathrm{ij}}=\mu+\mathrm{M}_{\mathrm{i}}+\mathrm{A}_{\mathrm{j}}+\varepsilon_{\mathrm{ij}}
$$

where $y_{i j}$ is the AFM1 level, $\mu=$ is the general mean, $M_{i}$ is the method effect, $A_{j}$ is the year effect, and $\varepsilon_{i j}$ is the residual error. The results were statistically analyzed using SPSS 17.0 for Windows (SPSS Inc., Chicago, IL).

The mean values for the chemical composition and the SCC of the bulk tank and silo milk samples (Table 1) were comparable and fall within the normal ranges for the Manchega ewe breed (Arias, 2009). However, no data have been published about curd composition because it is an intermediate product in the Manchego cheese-making process, although an obvious concentration in the total solids value can be observed between silo milk (18.9\%) and curd (41.2\%). The median levels for AFM1 following the 2 ELISA methods are presented in Figure 1. A tendency was observed for the AFM1 level to increase from the milk to the curd, owing to the occurring toxin concentration. The AFM1 concentrations detected by ELISA method 1 were always lower than those detected by ELISA method 2, but no significant differences were observed when comparing the results obtained by both methods $(P>0.05)$ for the 3 sample types analyzed. This behavior has been described previously by Rubio et al. (2009b) studying 5 methods, 


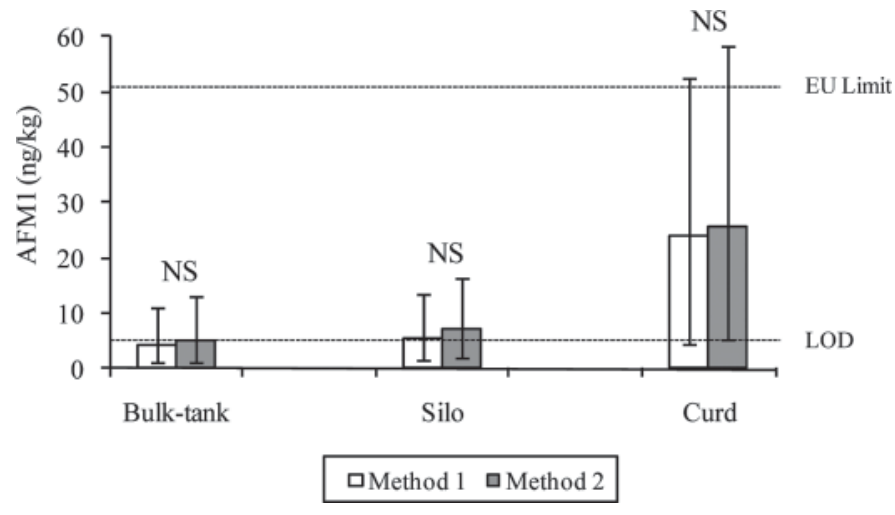

Figure 1. Medians of aflatoxin M1 (AFM1) concentration in the bulk tank milk $(\mathrm{n}=407)$, silo milk $(\mathrm{n}=82)$, and curd samples $(\mathrm{n}=$ 82) using 2 ELISA methods. NS = no significant difference; the bars surrounding the medians indicate the interquartile range $\left(\mathrm{IQR}=\mathrm{Q}_{3}-\right.$ $\left.\mathrm{Q}_{1}\right) . \mathrm{EU}=$ European Union; $\mathrm{LOD}=$ limit of detection.

with mean recovery percentages of 92.3 and $103.2 \%$ for ELISA methods 1 and 2, respectively. Very low levels of AFM1 contamination were obtained for bulk tank milk (4.3 and $5.3 \mathrm{ng} / \mathrm{kg}$ ) and silo milk (5.7 and $7.1 \mathrm{ng} / \mathrm{kg}$ ) and were close to the LOD for both methods $(5 \mathrm{ng} / \mathrm{kg})$. The values for curd (24 and $25.8 \mathrm{ng} / \mathrm{kg}$ ) were higher, but never exceeded $50 \mathrm{ng} / \mathrm{kg}$. In general, no significant differences were found when comparing the results from both study years (Table 2), although the values for curd analyzed by ELISA method 2 were slightly higher in yr $2(28.1$ vs. $24.6 \mathrm{ng} / \mathrm{kg})$ and were significantly different $(P<0.05)$. The level of contamination was still low despite the screening period selected (autumn and winter), which coincides with the months of higher AFM1 incidence (Tajkarimi et al., 2007; Hussain and Anwar, 2008) because of climatic conditions that increase the AFB1 contamination of feeds. We can assume, therefore, that AFM1 levels would be lower for the rest of the year. The results presented a wide variation range (Table 2); however, in the 5 distribution groups formed in accordance with the AFM1 level, $99.3 \%$ of the bulk tank milk and the $98.8 \%$ of the silo milk samples were below the EU limit. These are similar results to those of Decastelli et al. (2007), who reported that $98.3 \%$ of samples were below the EU limit in a study performed in Italy with raw cow milk $(\mathrm{n}=296)$; however, in goat $(\mathrm{n}=208)$ and ewe $(\mathrm{n}=54)$ milk samples in the same country (Kaniou-Grigoriadou et al., 2005; Virdis et al., 2008), all values were below the aforementioned limit. These circumstances may be explained by the lower number of samples analyzed and, in accordance with Hussain and Anwar (2008), the study period (spring or summer), when AFM1 incidence is lower.

For the samples from the cheese factories, 1 silo milk sample was over the EU limit, with values of 129.9 and $141.8 \mathrm{ng} / \mathrm{kg}$, and the corresponding manufactured curd presented levels of 522.3 and $227.8 \mathrm{ng} / \mathrm{kg}$ for ELISA methods 1 and 2, respectively. The AFM1 enrichment in the curd in relation to the original milk may be explained by the affinity of this mycotoxin for caseins (Applebaum et al., 1982). This curd was monitored until a 5-mo ripened Manchego cheese had been achieved, in which the concentrations were 774.8 and $426.7 \mathrm{ng} /$ $\mathrm{kg}$ for ELISA methods 1 and 2, respectively. This increase in AFM1 concentration observed in the cheese could be attributed to the augmentation of the protein percentage from curd $(15.8 \%)$ to cheese $(24.5 \%)$. In this study, an average 4-fold increase in median AFM1 level occurred from silo milk to curd, and was even higher for the cheese ripened for 5 mo. These results are similar to those reported by Kaniou-Grigoriadou et al. (2005) for Feta cheese analyzed by an ELISA method. In Italy, Montagna et al. (2008) and Virdis et al. (2008) found that 16.1 and $9.8 \%$ of sheep and goat cheeses, respectively, had AFM1 concentrations $>50 \mathrm{ng} / \mathrm{kg}$, a high incidence compared with the finding of $1.2 \%$ in the present study. Therefore, this is a satisfactory situation in relation to the low AFM1 incidence found in samples from the region, which corroborates the results of López-Diaz et al. (1996), although they analyzed only 12 Manchego cheeses using a method with a LOD of $100 \mathrm{ng} / \mathrm{kg}$.

In conclusion, low levels of AFM1 were detected in the present study, with $99.3 \%$ of the bulk tank ewe milk samples having AFM1 concentrations below the EU limit of $50 \mathrm{ng} / \mathrm{kg}$. Moreover, in cheese factories,

Table 2. Aflatoxin M1 (AFM1) contamination levels (ng/kg) in bulk tank milk, silo milk, and curd samples ${ }^{1}$ assessed by using 2 ELISA methods

\begin{tabular}{|c|c|c|c|c|c|c|c|c|c|}
\hline Method & Sample & \multicolumn{2}{|c|}{ Median } & Range & \multicolumn{5}{|c|}{ Distribution (n) } \\
\hline \multirow{2}{*}{1} & Silo milk & 6.1 & 5.5 & $0.4-129.9$ & 32 & 40 & 7 & 2 & 1 \\
\hline & Curd & 20.8 & 25.3 & $2-522.3$ & 8 & 4 & 11 & 58 & 1 \\
\hline \multirow[t]{2}{*}{2} & Bulk tank milk & 5.8 & 5 & $2.2-97.1$ & 184 & 161 & 48 & 10 & 4 \\
\hline & Silo milk & 8 & 5.8 & $2.6-141.8$ & 17 & 49 & 15 & 0 & 1 \\
\hline
\end{tabular}

${ }^{1}$ Bulk tank milk $(\mathrm{n}=407)$, silo milk $(\mathrm{n}=82)$, curd $(\mathrm{n}=82)$. 
98.8\% of silo milk and curds had levels of AFM1 below the EU limit. In accordance with these results, dairy products manufactured from Manchega ewe milk are of very high quality and safe in relation to AFM1.

\section{ACKNOWLEDGMENTS}

This study was financed by the Research Project PAI06-0068-3875 from the Junta de Comunidades de Castilla-La Mancha awarded to R. Rubio as a predoctoral grant (Ref. 07/039). The authors thank the personnel from the Centro Regional de Selección y Reproducción Animal (Valdepeñas, Spain), Consejo Regulador de la Denominación de Origen Queso Manchego (Valdepeñas, Spain), Asociación de Ganaderos de la Raza Manchega (Albacete, Spain) for their help with the milk composition and somatic cell analyses, and in collecting samples.

\section{REFERENCES}

Applebaum, R., R. E. Brackett, D. W. Wiseman, and E. H. Marth. 1982. Aflatoxin: Toxicity to dairy cattle occurrence in milk and milk products. J. Food Prot. 45:752-777.

Arias, R. 2009. Recuento de células somáticas y calidad de la leche de oveja en Castilla-La Mancha. PhD Thesis. Universidad de CastillaLa Mancha, Albacete, Spain.

Boudra, H., J. Barnouin, S. Dragacci, and D. P. Morgavi. 2007. Aflatoxin M1 and ochratoxin A in raw bulk milk from French dairy herds. J. Dairy Sci. 90:3197-3201.

Codex Alimentarius Commission. 2001. Comments submitted on the draft maximum level for aflatoxin M1 in milk. Codex committee on food additives and contamination, 33rd session. The Hague, the Netherlands.

Dashti, B., S. Al-Hamli, H. Alomirah, S. Al-Zenki, A. Bu Abbas, and W. Sawaya. 2009. Levels of aflatoxin M1 in milk, cheese consumed in Kuwait and occurrence of total aflatoxin in local and imported animal feed. Food Contr. 20:686-690.

De Iongh, H., R. O. Vles, and G. J. Van Pelt. 1964. Milk of mammals fed an aflatoxin-containing diet. Nature 202:466-467.

Decastelli, L., J. Lai, M. Gramaglia, A. Monaco, C. Nachtmann, F. Oldano, M. Ruffier, A. Sezian, and C. Banderola. 2007. Aflatoxins occurrence in milk and feed in Northern Italy during 2004-2005. Food Contr. 18:1263-1266.

European Union. 1996. Council Directive 96/23/EC of 29 April 1996 on measures to monitor certain substances and residues thereof in live animals and animal products and repealing Directives 85/358/ EEC and 86/469/EEC and Decisions 89/187/EEC and 91/664/ EEC. Off. J. L125:10-32.

European Union. 2003. Regulation (EC) No 2174/2003 of 12 December 2003, amending Regulation (EC) No 466/2001 as regards aflatoxins. Off. J. L326:12-15.

European Union. 2004. Regulation (EC) No 853/2004 of 29 April 2004, laying down specific hygiene rules for on the hygiene of foodstuffs. Off. J. L139:119-127.
Finoli, C., and A. Vecchio. 2003. Occurrence of aflatoxins in feedstuff, sheep milk and dairy products in western Sicily. Ital. J. Anim. Sci. 2:191-196.

Hussain. I., and J. Anwar. 2008. A study on contamination of aflatoxin M1 in raw milk in the Punjab province of Pakistan. Food Contr. 19:393-395.

International Agency for Research on Cancer (IARC). 2002. Some traditional herbal medicines, some mycotoxins, naphthalene and styrene. IARC Monographs Vol. 82. IARC, Lyon, France.

International Standards Organisation (ISO). 2007. Milk and milk powder. Determination of aflatoxin M1 content. Clean-up by immunoaffinity chromatography and determination by HPLC. Standard 14501. ISO, Geneva, Switzerland.

Kaniou-Grigoriadou, I., A. Eleftheriadou, T. Mouratidou, and P. Katikou. 2005. Determination of aflatoxin M1 in ewe's milk samples and the produced curd and Feta cheese. Food Contr. 16:257-261.

Kolosova, A. Y., W.-B. Shim, Z.-Y. Yang, S. A. Eremin, and D.-H. Chung. 2006. Direct competitive ELISA based on a monoclonal antibody for detection of aflatoxin B1. Stabilization of ELISA kit components and application to grain samples. Anal. Bioanal. Chem. 384:286-294.

López-Diaz, T. M., C. Román, M. T. García, M. C. García, and M. L. García. 1996. Mycotoxins in two Spanish cheese varieties. Int. J. Food Microbiol. 30:391-395.

Magliulo, M., M. Mirasoli, P. Simoni, R. Lelli, O. Portanti, and A. Roda. 2005. Development and validation o fan ultrasensitive chemiluminescent enzyme immunoassay for aflatoxin M1 in milk. J. Agric. Food Chem. 53:3300-3305.

MMAMRM (Ministerio de Medio Ambiente y Medio Rural y Marino). 2008. Datos de las Denominaciones de Origen Protegidas (D.O.P.) e Indicaciones Geográficas Protegidas (I.G.P.) de productos agroalimentarios. Año 2008. Accessed Sept. 20, 2010. http:// www.marm.es/es/alimentacion/temas/calidad-agroalimentaria/ Agroalimentarios2008_tcm7-141828.pdf.

Montagna, M. T., C. Napoli, O. De Giglio, R. Iatta, and G. Barbuti 2008. Occurrence of aflatoxin M1 in dairy products in southern Italy. Int. J. Mol. Sci. 9:2614-2621.

Oveisi, M.-R., B. Jannat, N. Sadeghi, M. Hajimahmoodi, and A. Nikzad. 2007. Presence of aflatoxin M1 in milk and infant milk products in Tehran, Iran. Food Contr. 18:1216-1218.

Rubio, R., M. I. Berruga, and A. Molina. 2009a. Effect of preservatives on immunoenzymatic methods for the analysis of aflatoxin M1 in ewe's milk. Milchwissenschaft 64:431-433.

Rubio, R., M. I. Berruga, M. Román, and A. Molina. 2009b. Evaluation of immunoenzymatic methods for the detection of aflatoxin M1 in ewe's milk. Food Contr. 20:1049-1052.

Sarimehmetoglu, B., O. Kuplulu, and T. Haluk. 2004. Detection of aflatoxin M1 in cheese samples by ELISA. Food Contr. 15:45-49.

Tajkarimi, M., F. Shojaee Aliabadi, M. Salah Nejad, H. Pursoltani, A A. Motallebi, and H. Mahdavi. 2007. Seasonal study of aflatoxin M1 contamination in milk in five regions in Iran. Int. J. Food Microbiol. 116:346-349.

Torkar, K. D., and A. Vengušt. 2008. The presence of yeasts, moulds and aflatoxin M1 in raw milk and cheese in Slovenia. Food Contr. 19:570-577.

van Egmond, H. P., R. C. Schothorst, and M. A. Jonker. 2007. Regulations relating to mycotoxins in food. Perspectives in a global and European context. Anal. Bioanal. Chem. 389:147-157.

Virdis, S., G. Corgiolu, C. Scarano, A. L. Pilo, and E. P. L. De Santis. 2008. Occurrence of aflatoxin M1 in tank bulk goat milk and ripened goat cheese. Food Contr. 19:44-49. 